\title{
A Fuzzy Comprehensive Evaluation Method of Area Resource Carrying Capacity
}

\author{
Qin Wang \\ College of Applied Science and technology, Beijing Union University, Beijing, China \\ Corresponding author:wangyw430074@yeah.net
}

Received: November 28. Revised: December 30, 2020. Accepted: December 30, 2020.

\begin{abstract}
The evaluation of resource carrying capacity of Xiong'an New Area can clearly recognize the endowment characteristics, carrying capacity and carrying level of resources in Xiong'an New Area, which could provide certain theoretical guidance for the sustainable development of economy, society and ecology in the New Area. Based on the analysis of the current situation of resources in the New Area, following the main principles of scientific, dynamic, reflecting the coordination of human land relationship and sustainable development, from three aspects of land resources, water resources and mineral resources, 13 indexes of the per capita cultivated land area, per capita construction land area, per unit cultivated land productivity, per capita water resources, per unit effective irrigation area, utilization rate of water resources, water use efficiency, ore production per unit land use and geothermal field area are selected to build the evaluation index system of resource carrying capacity of the New Area. Based on the fuzzy comprehensive evaluation method, the resource carrying capacity of Xiong'an New Area from 2014 to 2018 is evaluated with the administrative areas of Xiong county, An'xin county and Rongcheng county (including Baiyangdian water area) as the main evaluation unit, which could provide policy guidance for the land, water and mineral resources management of the New Area.
\end{abstract}

Keywords - Resource carrying capacity evaluation, fuzzy comprehensive evaluation method, Xiong'an New Area, land resources capacity, water resources capacity, mineral resources capacity.

\section{INTRODUCTION}

$\mathrm{T}$ he establishment of Xiong'an New Area is a millennium plan and a national event. In April of 2018, the planning outline of Xiong'an New Area in Hebei province was officially promulgated, which clearly pointed out that "adhere to the rigid constraints of resource carrying capacity, and scientifically determine the development boundary, population scale, land use scale and development intensity of the new area". Therefore, the objective and accurate evaluation of the resource carrying capacity of the New Area can provide countermeasures for the coordinated development of the resource system and the social economic system, and walk out a path of resource saving, environment-friendly regional green development and sustainable development. Based on the evaluation index system of resource carrying capacity of the New Area, in this paper the fuzzy comprehensive evaluation method is used to evaluate the resource carrying capacity of the New Area dynamically, which provides the basis for the development and utilization of resources, the strategic planning of the and economic development in the New Area.

\section{ANALYsis ON The RESOURCES Of XIONG'AN NEW AREA}

Xiong'an New Area is positioned as a second-class city, which is planned to be developed first with a specific area as the starting area. The starting area is about $100 \mathrm{~km}^{2}$, the medium-term development area is about $200 \mathrm{~km}^{2}$ and the long-term control area is about $2000 \mathrm{~km}^{2}$. The New Area has obvious location advantages, convenient transportation, excellent ecological environment, low level of existing development, abundant development space, and basic conditions of high starting point and high standard development and construction. The current situation of resources in the New Area is analyzed from three aspects: land resources, water resources and mineral resources.

\section{A. Analysis on the land resources of Xiong'an New Area}

In 2017, the total land area of Xiong, An'xin and Rongcheng county under the jurisdiction of Xiong'an New Area is 1560.70 $\mathrm{km}^{2}$, and the land use structure shows the characteristics of "six fields, two constructions, one water and half forest". Among them, the cultivated land area is $958.16 \mathrm{~km}^{2}$, accounting for $61.4 \%$, the urban and rural construction land is $310.70 \mathrm{~km}^{2}$, accounting for $19.91 \%$, the wetland area with Baiyangdian as the main body is $194.26 \mathrm{~km}^{2}$ (only referring to the 
administrative boundary of the New Area Wetland area), accounting for $12.45 \%$, forest land area is $97.58 \mathrm{~km}^{2}$, accounting for $6.25 \%$.

1) The dynamic change of land use is sharp, which is higher than the average level of Beijing-Tianjin-Hebei region.
From 2000 to 2018, the dynamic change area of the first-class land use type in three counties of Xiong'an New Area is $219.50 \mathrm{~km}^{2}$, accounting for $13.93 \%$ of the area, which is higher than the average level of Beijing-Tianjin-Hebei in the same period by $7.21 \%$, as shown in Table 1 .

Table 1 Land use area change of three counties in Xiong'an New Area from 2000 to 2018 (unit: $\mathrm{km}^{2}$ )

\begin{tabular}{cccccc}
\hline Land change & Cultivated land & Wood land & waters & $\begin{array}{c}\text { Urban and rural industrial } \\
\text { and mining residential land }\end{array}$ & $\begin{array}{c}\text { Non cultivated land in } \\
\text { cultivated land }\end{array}$ \\
\hline Newly added & 54.11 & 6.36 & 59.18 & 70.06 & 29.79 \\
Reduce & 90.56 & 0.46 & 83.69 & 0.28 & 44.50 \\
Net change & -36.45 & 5.90 & -24.51 & 69.78 & -14.71 \\
\hline
\end{tabular}

(Note: the above data source from 《Xiong'an New Area Development Research Report》)

2) The cultivated land resources are abundant, but the quality and utilization intensity are quite different.

The cultivated land area of the Xiong'an New Area accounts for more than $60 \%$, which provides enough space for the adjustment of human and land relationship. However, the cultivated land quality and utilization intensity of the three counties are quite different. The cultivated land quality of An'xin and Rongcheng county is good, and the multiple cropping index is high, reaching 1.92 and 1.87 respectively, winter wheat and summer maize are planted in turn on most cultivated land, with high utilization intensity. However, the cultivated land quality of Xiong county is relatively poor, and the multiple cropping index is obviously low, only 1.32, most of the cultivated land is mainly planted with corn and potato crops in summer, and the planting area of winter wheat is small [1].

3) The saving and intensive potential of construction land is great.

The existing urban and rural construction land in the New Area is nearly $290 \mathrm{~km}^{2}$, accounting for nearly $20 \%$ of the land area. Among them, the total built-up areas (state-owned construction land) of Xiong, An'xin and Rongcheng county is about $35 \mathrm{~km}^{2}$, accounting for $10 \%$ of the construction land area of the New Area. The permanent population of the county is 243000 , and the per capita construction land area is $123.5 \mathrm{~m}^{2}$. The collective construction land area of rural (including towns) is $252.17 \mathrm{~km}^{2}$, with a population of 884000 , and the per capita construction land area is $285 \mathrm{~m}^{2}$, and the rural construction land has great saving and intensive potential [2].

4)The distribution of wetland and forest land is less, and the ecological space needs to be optimized.
The wetland area of the New Area is $194.26 \mathrm{~km}^{2}$, about $92 \%$ of which is under the jurisdiction of An'xin county. Baiyangdian is the main part of the wetland in the New Area, which is of great significance to maintain the ecological security and improve the landscape diversity. The woodland area of the New Area is $97.58 \mathrm{~km}^{2}$, the forest coverage is only $6.3 \%$, and the fast-growing poplar is the main forest species [3]. From the perspective of planning and building a livable city, for the New Area, there is a huge space to improve forest coverage and optimize forest species structure in the future.

\section{B. Analysis on the water resources of Xiong'an New Area}

The total water resources and annual average precipitation of Baoding city where the Xiong'an New Area is located are 2978 billion $\mathrm{m}^{3}$ and $567 \mathrm{~mm}$ respectively, including 1620 billion $\mathrm{m}^{3}$ of surface water resources and 2223 billion $\mathrm{m}^{3}$ of groundwater resources. In 2016, the per capita water resources of Baoding city was $287 \mathrm{~m}^{3}$ [4]. Xiong'an New Area is rich in water systems, including Baiyangdian, which is the largest freshwater lake in North China. Baiyangdian is located in the middle and lower reaches of the Daqing River system, with a water area of about $366 \mathrm{~km}^{2}$, which includes 143 lakes and more than 3700 ditches.

1) Total water resources and per capita water resources are insufficient

In recent years, the average precipitation of the New Area is $516 \mathrm{~mm}$, and the total amount of water resources is 173 million $\mathrm{m}^{3}$, including 11 million $\mathrm{m}^{3}$ surface water resources, 169 million $\mathrm{m}^{3}$ groundwater resources and 7 million $\mathrm{m}^{3}$ repetition, as shown in Table 2. In 2018, the population of the New Area is nearly 1.2 million, and the per capita water resource is only 144 $\mathrm{m}^{3}$, which is lower than that of Baoding city $\left(282 \mathrm{~m}^{3}\right)$ and Beijing-Tianjin-Hebei in the same period $\left(248 \mathrm{~m}^{3}\right)$.

Table 2 Annual average water resources of three counties in Xiong'an New Area 


\begin{tabular}{|c|c|c|c|c|}
\hline County name & $\begin{array}{c}\text { Rainfall } \\
\text { (mm per year) }\end{array}$ & $\begin{array}{c}\text { Surface water } \\
\text { resources (100 million } \\
\mathbf{m}^{3} \text { per year) }\end{array}$ & $\begin{array}{l}\text { Groundwater resources } \\
\left(100 \text { million } \mathrm{m}^{3} \text { per year }\right)\end{array}$ & $\begin{array}{c}\text { Total water resources } \\
\left(100 \text { million }^{3} \text { per }\right. \\
\text { year })\end{array}$ \\
\hline Xiong county & 518 & 0.0232 & 0.4413 & 0.4522 \\
\hline Rongcheng county & 514 & 0.0569 & 0.5797 & 0.6200 \\
\hline An'xin county & 517 & 0.0282 & 0.6667 & 0.6546 \\
\hline Total & 1549 & 0.1083 & 1.6877 & 1.7268 \\
\hline
\end{tabular}

(Note: the above data source from 《Xiong'an New Area Development Research Report》)

2) Serious over exploitation of water resources has approached the carrying limit of water resources

In 2018 , the total water consumption of the three counties in the New Area is 258 million $\mathrm{m}^{3}$, of which the development and utilization of groundwater is 232 million $\mathrm{m}^{3}$, accounting for $90 \%$ of the total water consumption [5]. It can be seen that due to the influence of geographical location and local economic structure, the groundwater in three counties has been overexploited to varying degrees, which makes the water depth deeper and deeper. From 2006 to 2015, the underground water depth of Xiong county is decreased from $17.8 \mathrm{~m}$ to $19.2 \mathrm{~m}$, An'xin county from $7.8 \mathrm{~m}$ to $10.8 \mathrm{~m}$, Rongcheng county from $19.2 \mathrm{~m}$ to $22.5 \mathrm{~m}$.
3) Significant water deficit and low sustainability

In 2018, the deficit of water resources in the New Area is 85 million $\mathrm{m}^{3}$, and the sustainability of water resources is 0.623 . By comparison, Beijing and Hebei have larger deficits, 384 million $\mathrm{m}^{3}$ and 1838 million $\mathrm{m}^{3}$ respectively. But the sustainability of water resources in Beijing and Hebei is slightly higher than that in the New Area, 0.706 and 0.685 respectively, as shown in Table 3. Beijing and Hebei (including the New Area) is generally a region lacking water resources, and the sustainability of water resources is relatively low.

Table 3 Comparison of water resources utilization sustainability in Xiong'an New Area, Hebei and Beijing in 2018

\begin{tabular}{|c|c|c|c|c|}
\hline Area & $\begin{array}{c}\text { Total water resources } \\
\left(\mathbf{1 0 0} \text { million } \mathbf{m}^{3} \text { per year }\right)\end{array}$ & $\begin{array}{l}\text { Total water consumption } \\
\text { (100 million } \mathbf{m} 3 \text { per year) }\end{array}$ & $\begin{array}{c}\text { Water deficit } \\
(100 \text { million m3 per year) }\end{array}$ & Sustainability \\
\hline $\begin{array}{c}\text { Xiong'an New } \\
\text { Area }\end{array}$ & 1.73 & 2.58 & 0.85 & 0.623 \\
\hline Beijing & 35.46 & 39.3 & 3.84 & 0.706 \\
\hline Hebei & 164.04 & 182.42 & 18.38 & 0.685 \\
\hline
\end{tabular}

(Note: the above data source from 《Beijing Water Resources Bulletin》, 《Hebei Water Resources Bulletin》,

《Xiong'an New Area Development Research Report》)

4) Low efficiency of water resources output

In 2018, water consumption per 10000 yuan of GDP in the New Area is $139.84 \mathrm{~m}^{3}$, higher than $50.66 \mathrm{~m}^{3}$ in Hebei, and far higher than $12.96 \mathrm{~m}^{3}$ in Beijing, as shown in Table 4. This shows that the efficiency of water resources output in the New Area is relatively low, and it is necessary to introduce science, technology and water-saving industries to improve the efficiency of water resources output .

Table 4 Comparison of water consumption per 10000 yuan of GDP in Xiong'an New Area, Hebei and Beijing in 2018

\begin{tabular}{|c|c|c|c|}
\hline Area & $\begin{array}{l}\text { Total water consumption } \\
\left(\mathbf{1 0 0} \text { million } \mathbf{~ m}^{\mathbf{3}}\right)\end{array}$ & $\begin{array}{c}\text { GDP } \\
(\mathbf{1 0 0} \text { million yuan })\end{array}$ & $\begin{array}{l}\text { Water consumption per } \\
10000 \text { yuan of GDP }\left(\mathrm{m}^{3}\right)\end{array}$ \\
\hline Xiong'an New Area & 2.58 & 184.5 & 139.84 \\
\hline Hebei & 182.42 & 36010 & 50.66 \\
\hline
\end{tabular}



《Hebei Water Resources Bulletin》)

\section{5) Water resource gap continues to increase}

In terms of per capita water consumption, Beijing is $178.6 \mathrm{~m}^{3}$ in 2016 , while Hebei is $245.2 \mathrm{~m}^{3}$ in the same period. In the future, if there are 500000 people in Xiong'an New Area, the annual water demand is 89.3 million $\mathrm{m}^{3}$. If there are 1 million people in the new area, the annual water demand is 178.6 million $\mathrm{m}^{3}$, which is basically the same as the total water resources in the New Area. According to the overall planning of the New Area, the population development scale will reach 2-2.5 million in the medium term in the future. If calculated according to per capita water consumption of Beijing, it will need 357 450 million $\mathrm{m}^{3}$ and the water resource gap will reach 180 280 million $\mathrm{m}^{3}[6]$.

\section{Analysis on the mineral resources of Xiong'an New Area}

Xiong'an New Area has unique advantages in oil, natural gas, geothermal and other mineral resources. Xiong county is the main production area of Huabei oilfield, with more than 1200 oil wells, with an annual output of $700000 \mathrm{t}$ crude oil and 18 million $\mathrm{m}^{3}$ natural gas. The building sand and stone materials in the New Area are mainly distributed in Taihang Mountain and Yanshan area, while the brick clay is distributed in the plain area in the middle and eastern part of Hebei, including 150 cement limestone with an annual output of 39.6 million tons, 308 construction stone limestone with an annual output of 19.7 million tons, 21 construction sand with an annual output of 39.6 million tons, 634 brick clay with an annual output of 11.5 million tons, 367 dolomites for construction with an annual output of 65.5 million tons [7].

The New Area is rich in geothermal resources. As of 2019, the bedrock thermal storage area of Xiong county is $320 \mathrm{~km}^{2}$, accounting for $61 \%$ of the total area of the county, accounting for $50 \%$ of the total area of the geothermal field in Niutuo town. carrying capacity is an important carrier of the study of human land interaction. Therefore, it is necessary to base on the objective reality of the evaluation area, fully reflect the human land relationship characteristics of the resource carrying capacity of Xiong'an New Area, and depict the human land interaction mechanism of the New Area. (4) Sustainable development principle. The selection of indexes should consider the sustainable utilization of regional resources, and the evaluation results should reflect the sustainable development capacity of resource system in Xiong'an New Area.

Table 5 Preliminary construction of evaluation index system of resource carrying capacity of Xiong'an New Area
The geothermal water reserve is 82.178 billion $\mathrm{m}^{3}$, equivalent to 6.63 billion tons of standard coal.

\section{DESIGN OF EVALUATION INDEX SYSTEM OF RESOURCE CARRYING CAPACITY IN XIONG'AN NEW AREA}

\section{A. Design idea}

Combined with the resource situation of Xiong'an New Area, in this paper, the evaluation index system of resource carrying capacity of the New Area is designed from the three dimensions of land resources, water resources and mineral resources, to select the several second-class indexes according to the actual situation of the development of the New Area, and optimize the selection of each characteristic index by using the correlation analysis and principal component analysis of SPSS. Finally, the evaluation index system of resource carrying capacity of the New Area is designed to meet the regional characteristics.

\section{A. Design principles}

The design of evaluation index system of resource carrying capacity of Xiong'an New Area follows five main principles [8][9]: (1) Scientific principle. The evaluation indexes should be able to objectively and truly reflect the regional development status, fully reflect the essential characteristics of resources of Xiong'an New Area, at the same time the index requires clear concept, data availability and statistical norms, to ensure objective, scientific and effective evaluation results. (2) Dynamic principle. Xiong'an New Area is in the initial planning and development stage, and the resource carrying capacity will continue to be changed dynamically. Therefore, the evaluation indexes should be able to fully describe and evaluate the operation mode and development state of the resource system in the New Area. (3) Reflecting the coordination of human land relationship. The regional resource

\section{B. Design of evaluation index system}

Based on the first-class indexes of land resources, water resources and mineral resources, a total of 28 second-class indexes that best reflect the resource characteristics of Xiong'an New Area and statistical data can be checked or calculated are selected to initially build the evaluation index system of resource carrying capacity of the New Area [10][11], as shown in Table 5.
Name
First-class indexes
Second-class indexes

Evaluation land resources

total land area, per capita cultivated land area, per capita construction land area, per 


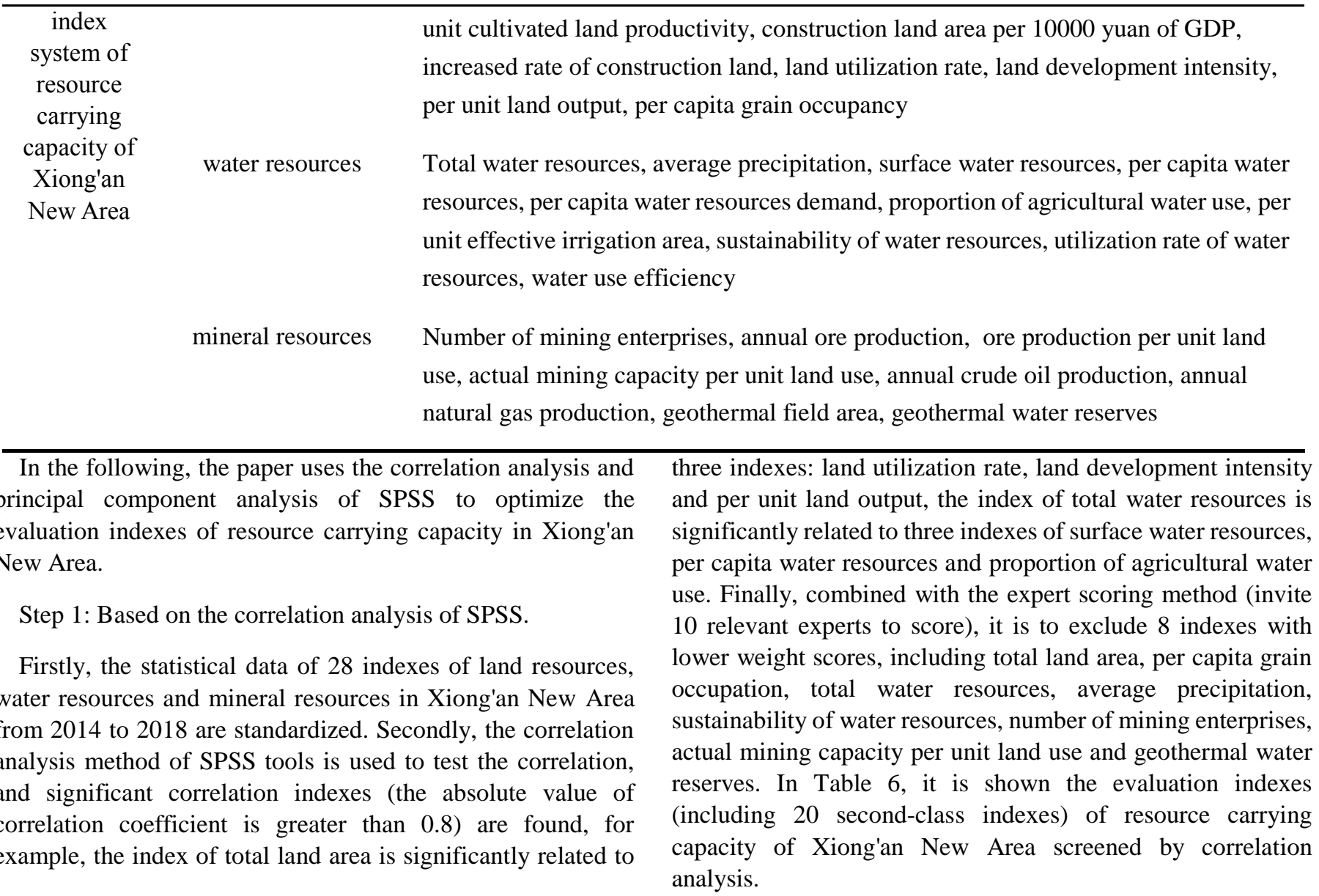

Table 6 Evaluation indexes of resource carrying capacity of Xiong'an New Area after correlation analysis

\begin{tabular}{|c|c|c|c|c|}
\hline Name & $\begin{array}{l}\text { First-class } \\
\text { Indexes }\end{array}$ & $\begin{array}{l}\text { Second-class } \\
\text { indexes }\end{array}$ & Index meaning & $\begin{array}{c}\text { Positive or } \\
\text { negative }\end{array}$ \\
\hline \multirow{8}{*}{$\begin{array}{l}\text { Evaluation } \\
\text { index } \\
\text { system of } \\
\text { resource } \\
\text { carrying } \\
\text { capacity of } \\
\text { Xiong'an } \\
\text { New Area }\end{array}$} & $\begin{array}{c}\text { Land } \\
\text { resources }\end{array}$ & $\begin{array}{l}\text { per capita cultivated land area } \\
\qquad\left(\mathrm{m}^{2} \text { per capita }\right)\end{array}$ & $\begin{array}{l}\text { Cultivated land area / } \\
\text { Total population }\end{array}$ & + \\
\hline & & $\begin{array}{l}\text { per capita construction land area } \\
\qquad\left(\mathrm{m}^{2} \text { per capita }\right)\end{array}$ & $\begin{array}{l}\text { Construction land area / } \\
\text { Total population }\end{array}$ & + \\
\hline & & $\begin{array}{l}\text { per unit cultivated land productivity } \\
\qquad\left(\mathrm{t} \text { per } \mathrm{km}^{2}\right)\end{array}$ & Crop yield / Cultivated land area & + \\
\hline & & $\begin{array}{l}\text { construction land area per } 10000 \text { yuan of } \\
\operatorname{GDP}\left(\mathrm{m}^{2} \text { per } 10000 \text { yuan }\right)\end{array}$ & Construction land area / GDP & - \\
\hline & & increased rate of construction land (\%) & $\begin{array}{l}\text { Increased construction land area / Total } \\
\text { construction land area }\end{array}$ & + \\
\hline & & land utilization rate $(\%)$ & Used land area / Total land area & + \\
\hline & & land development intensity (\%) & Total construction land / Total land area & + \\
\hline & & $\begin{array}{l}\text { per unit land output } \\
\left(10000 \text { yuan per } \mathrm{km}^{2}\right)\end{array}$ & GDP / Total land area & + \\
\hline ISSN: 19 & 4464 & 1141 & & \\
\hline
\end{tabular}




$$
\begin{array}{cc}
\text { Water } & \text { surface water resources } \\
\text { resources } & \left(100 \text { million } \mathrm{m}^{3} \text { per year }\right) \\
& \text { per capita water resources } \\
& \left(\mathrm{m}^{3} \text { per capita }\right)
\end{array}
$$

per capita water resources demand

$$
\text { ( } \mathrm{m}^{3} \text { per capita) }
$$

proportion of agricultural water use (\%)

per unit effective irrigation area

$$
\left(\mathrm{m}^{2}\right. \text { per ton) }
$$

utilization rate of water resources (\%)

water use efficiency (yuan per $\mathrm{m}^{3}$ )

Mineral

resources ore production per unit land use

$$
\text { (10000 tons per } \mathrm{km}^{2} \text { ) }
$$

annual crude oil production

$$
\text { (ton per year) }
$$

annual natural gas production

$$
\left(10000 \mathrm{~m}^{3}\right)
$$

geothermal field area $\left(\mathrm{km}^{2}\right)$

geothermal water reserves
Total water resources /

Total population

Total water demand /

Total population

Total agricultural water consumption / +

Total water resources

Irrigation area / Water consumption of cultivated land

Water consumption /

Available water resources

GDP / Water supply

Annual ore output /

Mining land area
$+$

$+$

$+$

$+$

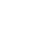

$-$

$+$

$-$

$+$

$+$

$+$

$+$

$\left(100\right.$ million $\mathrm{m}^{3}$ )

Step 2: Based on the principal component analysis of SPSS.

Firstly, standardize the statistical data of 20 indexes of land resources, water resources and mineral resources in Xiong'an New Area from 2014 to 2018. Secondly, use the principal component analysis method of SPSS tools for analysis. In Table 7, the characteristic values of the first four principal components of the resource carrying capacity index are all greater than 1 , and the cumulative contribution rate is more than $80 \%$, indicating that these four principal components can basically represent the original index to evaluate the resource carrying capacity of Xiong'an New Area. Finally, the related indexes are extracted based on the principal components. In
Table 8 , by analyzing the rotated factor load matrix, 13 indexes of the per capita cultivated land area, per capita construction land area, per unit cultivated land productivity, land utilization rate, per unit land output, per capita water resource, per unit effective irrigation area, utilization rate of water resources, water use efficiency, ore production per unit land use, annual crude oil yield, annual natural gas yield, geothermal field are extracted from the four main components to construct the evaluation index system of resource carrying capacity of Xiong'an New Area, as shown in Fig 1.

Table 7 Total Variance Explained

\begin{tabular}{crrrrrr}
\hline \multirow{2}{*}{ Component } & \multicolumn{3}{c}{ Initial Eigenvalues } & \multicolumn{3}{c}{ Rotation Sums of Squared Loading } \\
\cline { 2 - 6 } & \multicolumn{1}{c}{ Total } & \% of Variance & Cumulative \% & Total & \% of Variance & Cumulative \% \\
\hline 1 & 6.549 & 42.743 & 42.743 & 6.549 & 42.743 & 42.743
\end{tabular}


INTERNATIONAL JOURNAL OF CIRCUITS, SYSTEMS AND SIGNAL PROCESSING

\begin{tabular}{|c|c|c|c|c|c|c|}
\hline 2 & 2.932 & 24.659 & 67.402 & 2.932 & 24.659 & 67.402 \\
\hline 3 & 1.759 & 8.797 & 76.199 & 1.759 & 8.797 & 76.199 \\
\hline 4 & 1.260 & 6.802 & 83.001 & 1.260 & 6.802 & 83.001 \\
\hline 5 & 0.918 & 5.172 & 88.173 & & & \\
\hline 6 & 0.772 & 4.875 & 93.048 & & & \\
\hline 7 & 0.517 & 3.115 & 96.163 & & & \\
\hline 8 & 0.348 & 1.825 & 97.988 & & & \\
\hline 9 & 0.177 & 0.928 & 98.916 & & & \\
\hline 10 & 0.078 & 0.537 & 99.453 & & & \\
\hline 11 & 0.042 & 0.329 & 99.782 & & & \\
\hline 12 & 0.025 & 0.216 & 99.998 & & & \\
\hline 13 & 0.018 & 0.194 & 100.000 & & & \\
\hline 14 & $6.221 \mathrm{E}-16$ & $3.111 \mathrm{E}-15$ & 100.000 & & & \\
\hline 15 & $5.532 \mathrm{E}-16$ & $2.766 \mathrm{E}-15$ & 100.000 & & & \\
\hline 16 & $3.727 \mathrm{E}-16$ & $1.863 \mathrm{E}-15$ & 100.000 & & & \\
\hline 17 & $1.954 \mathrm{E}-16$ & $9.769 \mathrm{E}-16$ & 100.000 & & & \\
\hline 18 & $-4.206 E-16$ & $-2.103 \mathrm{E}-15$ & 100.000 & & & \\
\hline 19 & $-5.042 \mathrm{E}-16$ & $-2.521 \mathrm{E}-15$ & 100.000 & & & \\
\hline 20 & $-1.390 \mathrm{E}-15$ & $-6.949 \mathrm{E}-15$ & 100.000 & & & \\
\hline
\end{tabular}

Extraction Method: Principal Component Anaylsis

Table 8 Rotated Component Matrix ${ }^{\text {a }}$

\begin{tabular}{ccccc}
\hline & \multicolumn{4}{c}{ Component } \\
\cline { 2 - 5 } & 1 & 2 & 3 & 4 \\
\hline per capita cultivated land area & .919 & .288 & -.224 & .149 \\
per capita construction land area & .912 & .224 & -.072 & .338 \\
$\quad$ per unit cultivated land productivity & .364 & .928 & .044 & -.072 \\
construction land area per 10000 yuan of GDP & .254 & .634 & .198 & -.155 \\
$\quad$ increased rate of construction land & -.815 & -.524 & .236 & -.073 \\
land utilization rate & .998 & .055 & -.037 & .003 \\
land development intensity & .542 & .235 & -.237 & .035
\end{tabular}




\begin{abstract}
per unit land output
surface water resources

per capita water resources
\end{abstract}

per capita water resources demand

proportion of agricultural water use

per unit effective irrigation area

utilization rate of water resources

water use efficiency

ore production per unit land use

annual crude oil production

annual natural gas production

geothermal field area

geothermal water reserves
$-.066$

$-.254$

$-.288$

$-.856$

.413

.755

$-.161$

.961

.582

$-.131$

.975

.626

.677
.983

.447

.380

$-.165$

$-.264$

.098

.067

.157

.809

.719

.218

$-.101$

$-.144$

.553

.172

.175

.813

$-.484$

$-.854$

.643

.968

$-.078$

.064

.504

$-.024$

759

Extraction Method: Principal Component Anaylsis

\section{Ratation Method:Varimax with Kaiser Normalization}

a.Ratation converged in 5 iteratio

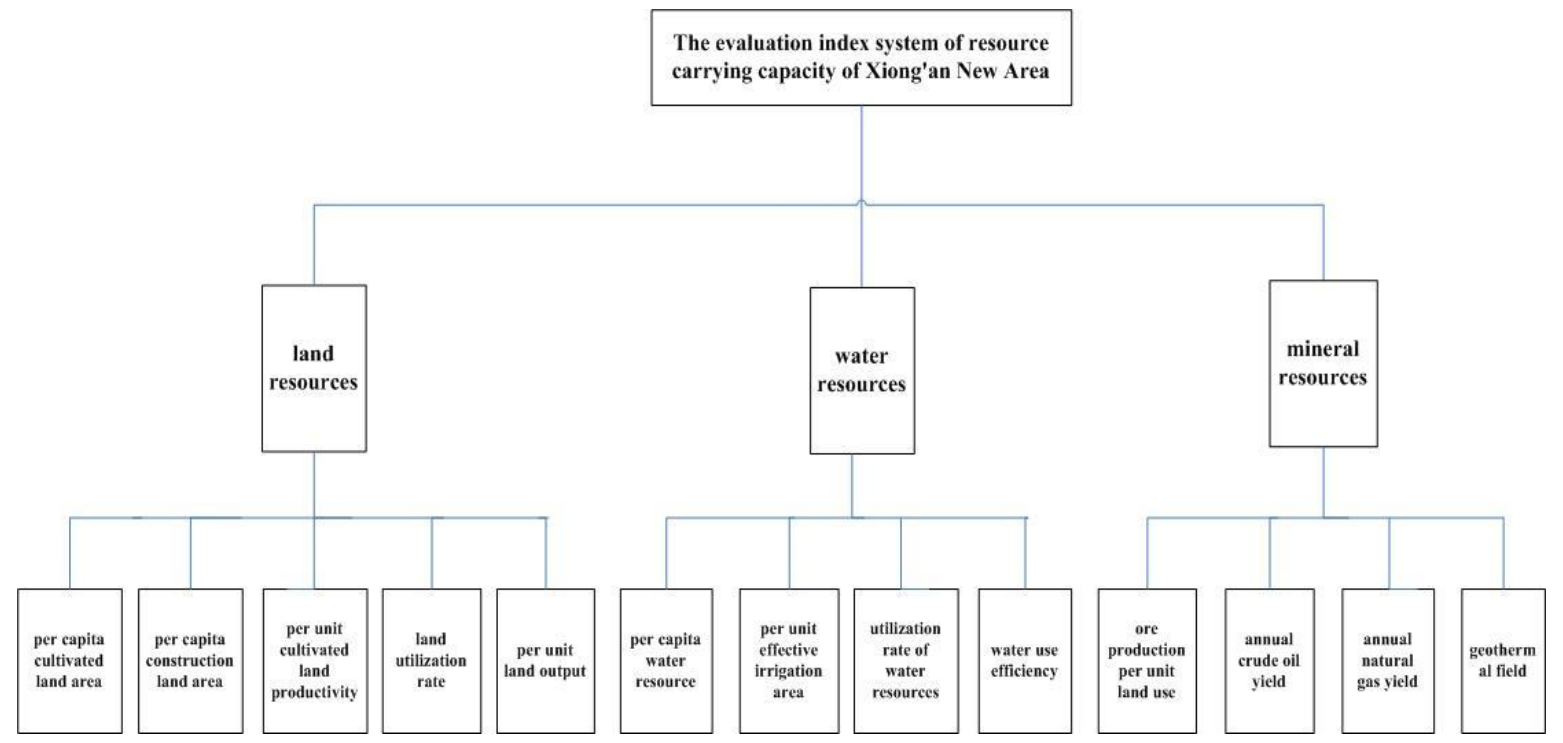

Fig.1 The evaluation index system of resource carrying capacity of Xiong'an New Area

\section{FUZZY COMPREHENSIVE EVALUATION METHOD}

\section{A. Overview of fuzzy comprehensive evaluation method}

Fuzzy comprehensive evaluation method is a comprehensive evaluation method based on fuzzy mathematics. According to the membership degree theory of fuzzy mathematics, qualitative evaluation is transformed into quantitative evaluation. That is to say, fuzzy mathematics is used to make an overall evaluation of things or objects restricted by various factors. It has the characteristics of clear results and strong systematization, which can solve the fuzzy and difficult to quantify problems and is suitable for solution of various kinds of uncertain problems. The evaluation of regional resources and 
environment carrying capacity is a very complex problem. All kinds of factors will affect the evaluation effect of resources and environment carrying capacity, and the way and size of the influence are different and fuzzy. The fuzzy comprehensive evaluation method can objectively reflect these effects, so it is more scientific and feasible.

\section{B. Main steps of fuzzy comprehensive evaluation method}

Main steps of fuzzy comprehensive evaluation method include [12]:

Step 1: Determine the factor set.

The factor set is divided into target level, first-class evaluation factor and second-class evaluation factor, namely: $U=\left(U_{1}, U_{2}, U_{3}, \ldots, U_{m}\right), U_{m}=\left(U_{m 1}, U_{m 2}, U_{m 3}, \ldots, U_{m n}\right), m, n>0$

。

Step 2: Determine the evaluation set.

In general, according to the characteristics of the selection of evaluation factors whose possible values are intervals in the comprehensive evaluation factor set, the evaluation set $v=\left\{v_{1}, v_{2}, v_{3}, \ldots, v_{n}\right\}$ is set as $\{$ very good, good, general, poor, very poor , and the evaluation is carried out by combining the limit optimal value or multiple schemes to compare the optimal value. In this paper, according to the influence degree of the evaluation index on resource carrying capacity of Xiong'an New Area, the evaluation index is divided into three levels: $v_{1}$ level of ideal carrying state, $v_{3}$ level of non-carrying state and $v_{2}$ level of carrying state (between $v_{1}$ and $v_{3}$ ).

Step 3: Building fuzzy matrix.

Firstly, build fuzzy membership function. Membership indicates the degree of membership corresponding to the evaluation result and the level standard. In this paper, according to the characteristics of resource evaluation, in order to eliminate the jump phenomenon that the value difference between different levels is not big and the evaluation level is one level different, it is to make the membership function smoothly transition between different levels and is to be blurred. Now, the critical value of the $v_{1}$ and $v_{2}$ level is $k_{1}$, the critical value of the $v_{2}$ and $v_{3}$ level is $k_{3}$, and the point value in the $v_{2}$ level interval is $k_{2}, k_{2}=\left(k_{1}+k_{3}\right) / 2$.

For the evaluation factors with higher index value and higher resource carrying capacity level, the calculation formula of relative membership function of each level is as follows in Formula1.

$$
\mathrm{u}_{\mathrm{vl}}=\left\{\begin{array}{cc}
0.5\left[1+\left(\mathrm{k}_{1}-\mathrm{U}_{\mathrm{i}}\right) /\left(\mathrm{k}_{2}-\mathrm{U}_{\mathrm{i}}\right)\right] & \mathrm{U}_{\mathrm{i}}>\mathrm{k}_{1} \\
0.5\left[1-\left(\mathrm{U}_{\mathrm{i}}-\mathrm{k}_{1}\right) /\left(\mathrm{k}_{2}-\mathrm{k}_{1}\right)\right] & \mathrm{k}_{2}<\mathrm{U}_{\mathrm{i}} \leq \mathrm{k}_{1}
\end{array}\right.
$$

$$
\begin{array}{cc}
0 & \mathrm{U}_{\mathrm{i}} \leq \mathrm{k}_{2} \\
\mathrm{u}_{\mathrm{v} 2}=\left\{\begin{array}{cc}
0.5\left[1-\left(\mathrm{k}_{1}-\mathrm{U}_{\mathrm{i}}\right) /\left(\mathrm{k}_{2}-\mathrm{U}_{\mathrm{i}}\right)\right] & \mathrm{U}_{\mathrm{i}}>\mathrm{k}_{1} \\
0.5\left[1+\left(\mathrm{U}_{\mathrm{i}}-\mathrm{k}_{1}\right) /\left(\mathrm{k}_{2}-\mathrm{k}_{1}\right)\right] & \mathrm{k}_{2}<\mathrm{U}_{\mathrm{i}} \leq \mathrm{k}_{1} \\
0.5\left[1+\left(\mathrm{k}_{3}-\mathrm{U}_{\mathrm{i}}\right) /\left(\mathrm{k}_{3}-\mathrm{k}_{2}\right)\right] & \mathrm{k}_{3}<\mathrm{U}_{\mathrm{i}} \leq \mathrm{k}_{2}
\end{array}\right. \\
\mathrm{u}_{\mathrm{v} 3}=\left\{\begin{array}{cc}
0.5\left[1-\left(\mathrm{k}_{3}-\mathrm{U}_{\mathrm{i}}\right) /\left(\mathrm{k}_{2}-\mathrm{U}_{\mathrm{i}}\right)\right] & \mathrm{U}_{\mathrm{i}} \leq \mathrm{k}_{3} \\
0.5\left[1+\left(\mathrm{k}_{3}-\mathrm{U}_{\mathrm{i}}\right) /\left(\mathrm{k}_{2}-\mathrm{U}_{\mathrm{i}}\right)\right] & \mathrm{U}_{\mathrm{i}}<\mathrm{k}_{3} \\
0.5\left[1-\left(\mathrm{U}_{\mathrm{i}}-\mathrm{k}_{3}\right) /\left(\mathrm{k}_{2}-\mathrm{k}_{3}\right)\right] & \mathrm{k}_{3} \leq \mathrm{U}_{\mathrm{i}}<\mathrm{k}_{2} \\
0 & \\
0 & \mathrm{U}_{\mathrm{i}} \geq \mathrm{k}_{2}
\end{array}\right.
\end{array}
$$

For the evaluation factors with smaller index value and higher resource carrying capacity level, the calculation formula of relative membership function of each level is as follows in Formula 2.

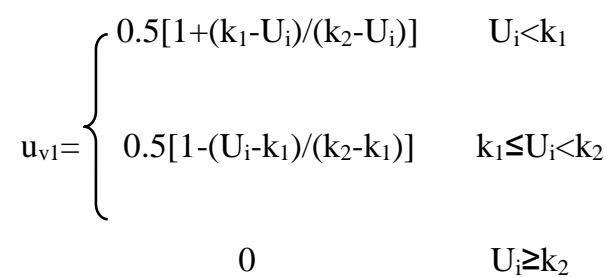

$\mathrm{u}_{\mathrm{v} 2}= \begin{cases}0.5\left[1-\left(\mathrm{k}_{1}-\mathrm{U}_{\mathrm{i}}\right) /\left(\mathrm{k}_{2}-\mathrm{U}_{\mathrm{i}}\right)\right] & \mathrm{U}_{\mathrm{i}}<\mathrm{k}_{1} \\ 0.5\left[1+\left(\mathrm{U}_{\mathrm{i}}-\mathrm{k}_{1}\right) /\left(\mathrm{k}_{2}-\mathrm{k}_{1}\right)\right] & \mathrm{k}_{1} \leq \mathrm{U}_{\mathrm{i}}<\mathrm{k}_{2} \\ 0.5\left[1+\left(\mathrm{k}_{3}-\mathrm{U}_{\mathrm{i}}\right) /\left(\mathrm{k}_{3}-\mathrm{k}_{2}\right)\right] & \mathrm{k}_{2} \leq \mathrm{U}_{\mathrm{i}}<\mathrm{k}_{3}\end{cases}$

$$
\mathrm{u}_{\mathrm{v} 3}=\left\{\begin{array}{cc}
0.5\left[1-\left(\mathrm{k}_{3}-\mathrm{U}_{\mathrm{i}}\right) /\left(\mathrm{k}_{2}-\mathrm{U}_{\mathrm{i}}\right)\right] & \mathrm{U}_{\mathrm{i}} \geq \mathrm{k}_{3} \\
0.5\left[1+\left(\mathrm{k}_{3}-\mathrm{U}_{\mathrm{i}}\right) /\left(\mathrm{k}_{2}-\mathrm{U}_{\mathrm{i}}\right)\right] & \mathrm{U}_{\mathrm{i}} \geq \mathrm{k}_{3} \\
0.5\left[1-\left(\mathrm{U}_{\mathrm{i}}-\mathrm{k}_{3}\right) /\left(\mathrm{k}_{2}-\mathrm{k}_{3}\right)\right] & \mathrm{k}_{2} \leq \mathrm{U}_{\mathrm{i}}<\mathrm{k}_{3} \\
0 & \\
0 & \mathrm{U}_{\mathrm{i}}<\mathrm{k}_{2}
\end{array}\right.
$$


Through the above Formula 1 and Formula 2, the membership $r_{i j}$ of each evaluation index corresponding to each level can be calculated,

$$
r_{i 1}=u_{v 1}\left(U_{i}\right), r_{i 2}=u_{v 2}\left(U_{i}\right), r_{i 3}=u_{v 3}\left(U_{i}\right),
$$

$(i=1,2,3 \ldots m)$.

Secondly, establish fuzzy relation matrix. Through calculation of membership, the fuzzy relation matrix $R_{m \times n}$ is established:

$$
R_{m \times n}=\left(\mathrm{r}_{\mathrm{ij}}\right)=\left|\begin{array}{ccc}
r_{11} & r_{12} & r_{13} \\
r_{21} & r_{22} & r_{23} \\
\cdots & \cdots & \cdots \\
r_{m 1} & r_{m 2} & r_{m 3}
\end{array}\right|
$$

$r_{i j}=\left(r_{i 1}, r_{i 2}, \ldots, r_{i n}\right)$ is the single index evaluation result of

the $i$-th index $U_{i}$ in the matrix $R$.

Step 4: Determine weight.

The weight vector is a set corresponding to the factor set, which is used to display the weight value of each index.

$$
\begin{aligned}
& W=\left(w_{1}, w_{2}, w_{3}, \ldots w_{m}\right) \\
& w_{m} \geq 0, \quad \sum w_{m}=1
\end{aligned}
$$

The evaluation index system of resource carrying capacity of Xiong'an New Area is a total of two-class indexes. Therefore, the expert scoring method and principal component analysis method are selected to determine the weights of the evaluation indexes.

The first-class evaluation index of resource carrying capacity evaluation index system in Xiong'an New Area uses expert scoring method to determine the weight. The specific method is to invite ten experts to fill in the questionnaire of index weight independently according to the requirements, and do not discuss or have any horizontal contact with each other. The principle of selecting experts is scholars who are proficient in relevant research, and the number of experts is selected to exclude personal subjective factors and the operability of investigation.

Principal component analysis method is used to determine the weight of the second-class evaluation index system of resource carrying capacity in Xiong'an New Area. The specific steps are: firstly calculate the coefficient of the index in the linear combination of the principal components, secondly calculate the variance contribution rate of the principal components, finally normalize the index weight.
Step 5: Select fuzzy operator pairs.

Select the fuzzy operator pair, that is, the weight vector $W$ and its corresponding fuzzy matrix $R$ for fuzzy transformation, and get the comprehensive evaluation results:

$$
B=W * R=\left(w_{1}, w_{2}, w_{3}, \cdots, w_{m}\right) *\left[\begin{array}{cccc}
r_{11} & r_{12} & \cdots & r_{1 j} \\
r_{21} & r_{22} & \cdots & r_{2 j} \\
\vdots & \vdots & \ddots & \vdots \\
r_{m 1} & r_{m 2} & \cdots & r_{m j}
\end{array} \mid=\left(b_{1}, b_{2}, b_{3}, \cdots, b_{j}\right)\right.
$$

The evaluation result $B$ is a fuzzy subset of $v$, $B=\left\{b_{1}, b_{2}, \ldots, b_{j}\right\}, 0 \leq b_{j} \leq 1, b_{j}$ is the membership of the fuzzy subsets $B$ obtained from the comprehensive evaluation $v_{j}$, which represents the results of the comprehensive evaluation. The weight vector $w=\left\{w_{1}, w_{2}, \ldots, w_{m}\right\}$ represents the weight index of the importance of each evaluation index to the comprehensive evaluation. According to the different influence degree of each evaluation index on the resource carrying capacity, each evaluation index is given different weights, to satisfy $w_{1}+w_{2}+\ldots+w_{m}=1$.

Score 0-1 interval for $v_{1}, v_{2}$ and $v_{3}$, the higher the index score value corresponding to the stronger carrying capacity, the scoring value corresponding to the grading indexes of $v_{1}, v_{2}$ and $v_{3}$ is $a_{1}, a_{2}, a_{3}$, take $a_{1}=0.95, a_{2}=0.5$ and $a_{3}=0.05$, and the calculation formula of comprehensive evaluation score is as follows in Formula 3.

$$
a=\frac{\sum_{j=1}^{3} b_{j} \alpha_{j}}{\sum_{j=1}^{3} b_{j}}
$$

$b_{j}$ is the $j t h$ value of the result matrix, $a$ represents resource carrying capacity in the region, and $a_{j}$ is between 0 and 1 . The closer the value of $a_{j}$ is to 1 , the greater the potential of resource carrying capacity is, the higher the regional resource carrying capacity is. The closer the value of $a_{j}$ is to 0 , the smaller the potential of resource carrying capacity is, the lower the regional resource carrying capacity is.

\section{EVALUATION OF RESOURCE CARRYING CAPACITY OF XIONG'AN NEW AREA BASED ON FUZZY COMPREHENSIVE EVALUATION METHOD}

\section{A. Definition of evaluation unit in Xiong'an New Area}

Taking Xiong county, An'xin county and Rongcheng county administrative area (including Baiyangdian water area) of Xiong'an New Area as the main evaluation unit, the research data is the statistical index data of the New Area from 2014 to 2018, all of which are from Hebei Economic Yearbook, Statistical Bulletin of National Economic and Social Development of Baoding, Hebei Economic Development 
Report, Website of Hebei Bureau of Statistics, Official Website of Xiong'an New Area, official websites of Xiong county, An'xin county and Rongcheng county, and to investigate or calculate the actual data.

\section{B. Evaluation of land resources carrying capacity in} Xiong'an New Area

Step 1: Set grading standard of evaluation index.

Based on the relevant policy documents such as urban system planning, urban land classification and planning and construction land standard, land use master plan, Xiong'an New Area Master Plan (2018 2035), combined with national land use level, actual land use situation and land use level of the New Area, referring to relevant literature, it has formulated the grading standards for each evaluation index of the land resources carrying capacity in the New Area.

(1) Per capita cultivated land area. At present, China's per capita cultivated land area is $1.499 \mathrm{Mu}$, just for one third of the world, and the per capita cultivated land area of Xiong'an New Area is $1.30 \mathrm{Mu}$, lower than the national average. According to the world recognized standard, the international warning line is $0.8 \mathrm{Mu}$ per capita. Combined with relevant literature and expert advice, so $k_{1}$ is selected as 1.5 and $k_{3}$ as 0.8 . (2) Per capita construction land area of Xiong'an New Area is $278.85 \mathrm{~m}^{2}$ per capita, which is far higher than the level of $84 \mathrm{~m}^{2}$ per capita in developed countries and $83 \mathrm{~m}^{2}$ per capita in the world average level. Combined with the relevant research results, so $k_{1}$ is selected as 300 and $k_{3}$ as 250. (3) Per unit cultivated land productivity. The average per unit cultivated land productivity is $650 \mathrm{t} / \mathrm{km}^{2}$ in China, and the per unit cultivated land productivity in Xiong'an New Area is $560.64 \mathrm{t} / \mathrm{km}^{2}$. Combined with relevant research results and expert opinions, so $k_{1}$ is selected as 650 and $k_{3}$ as 550. (4) Land use rate. Compared with the average level of $73.95 \%$ of the national land use rate, the land use rate of Xiong'an New Area is 62.8\%. Referring to the master plan of Xiong'an New Area in Hebei Province (2018-2035), so $k_{1}$ is selected as 75 and $k_{3}$ as 60. (5) Unit land output. According to the national average level of land efficiency of 9.3781 million yuan $/ \mathrm{km}^{2}$, and the unit land output of Xiong'an New Area of 11.8258 million yuan $/ \mathrm{km}^{2}$, combined with the 13th five year plan for national economic and social development, so $k_{1}$ is selected as 1200 and $k_{3}$ as 950 . Through the above grading standard selection process, determine the grading standard of land resources carrying capacity evaluation index in Xiong'an New Area, as shown in Table 9.

construction land area. The national per capita construction land area is $284.78 \mathrm{~m}^{2}$ per capita, and the per capita

Table 9The grading standard of land resources carrying capacity evaluation index in Xiong'an New Area

\begin{tabular}{lcccc}
\hline \multirow{2}{*}{ Name } & Evaluation indexes & \multicolumn{3}{c}{ Evaluation classification $v$} \\
\cline { 3 - 5 } & Per capita cultivated land area $($ Mu per capita) & $>1.5$ & $1.5 \sim 0.8$ & $v_{3}$ \\
\hline \multirow{2}{*}{ Land resources } & per capita construction land area $\left(\mathrm{m}^{2}\right.$ per capita) & $>300$ & $300 \sim 250$ & $<250$ \\
& per unit cultivated land productivity $\left(\mathrm{t} / \mathrm{km}^{2}\right)$ & $>650$ & $650 \sim 550$ & $<550$ \\
Land use rate $(\%)$ & $>75$ & $75 \sim 60$ & $<60$
\end{tabular}

According to different degrees of influence of the above five indexes on the regional land resources carrying capacity, it is divided into three grades of $v_{1}, v_{2}$ and $v_{3}$, which $v_{1}$ means better and the regional land has larger carrying capacity, and which $v_{3}$ means worse and the carrying capacity of land resources has become saturated, the further development potential is small. $v_{2}$ is between $v_{1}$ and $v_{3}$, which has certain development potential, but the potential is limited.

Step 2: Determine the weight of each index.

In this paper, principal component analysis is used to determine the weight of second-class evaluation indexes, as shown in Table 10.

Table 10 Weight of each evaluation index of land resources in Xiong'an New Area
Name
Evaluation indexes
Component 1
Component 2
Component 3
Component 4 


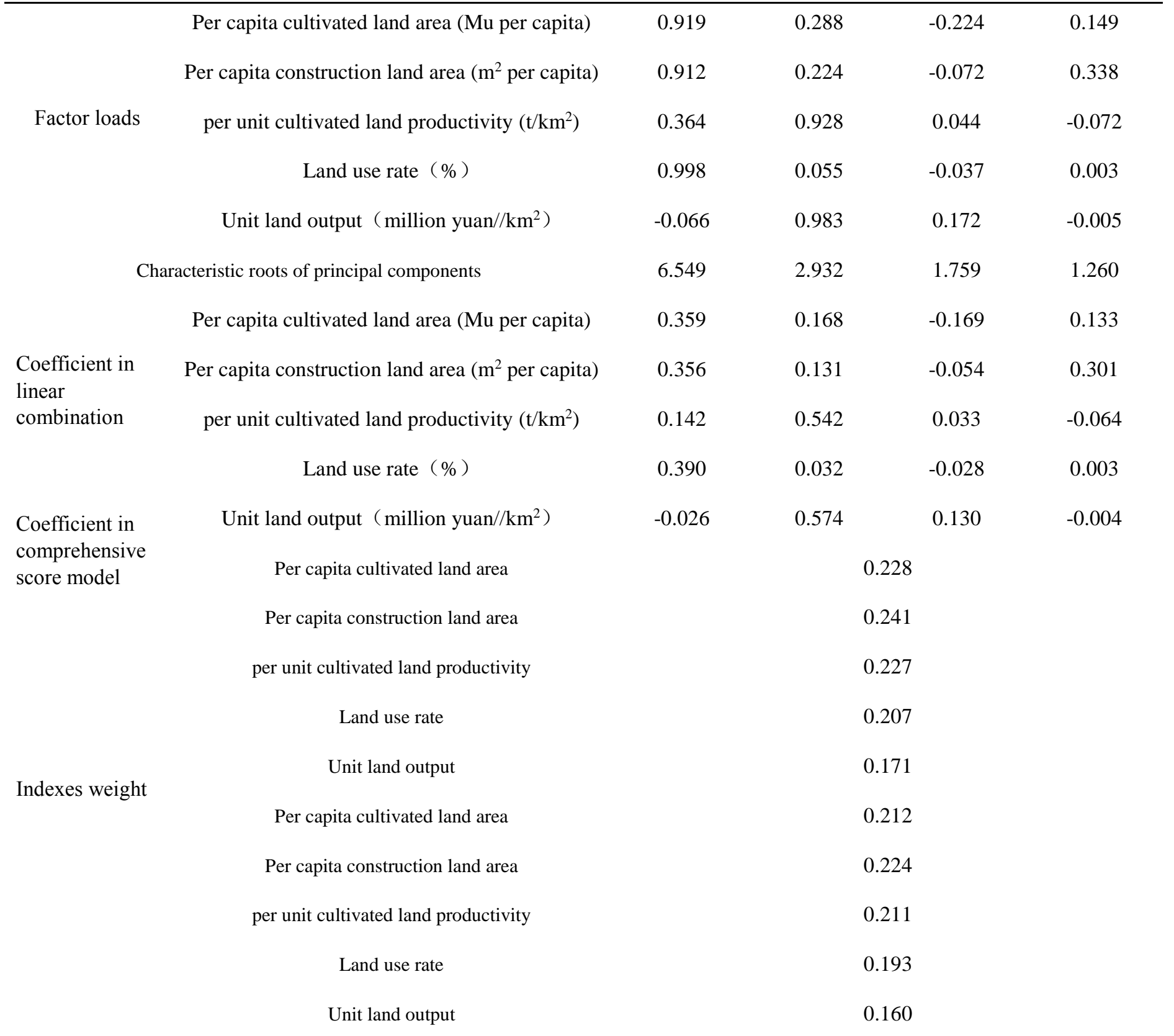

The weight matrix $W$ of evaluation index of land resources carrying capacity in Xiong'an New Area $=(0.212,0.224$, $0.211,0.193,0.160)$.

Step 3: Evaluate the carrying capacity of land resources.

First of all, the evaluation matrix $R$ of membership function is calculated. According to the evaluation index rating standard of land resources in Xiong'an New Area in Table 12, the basic data of five indexes of per capita cultivated land area, per capita construction land area, per unit cultivated land productivity, land use rate and unit land output from 2014 to 2018 are substituted into Formulas 1, and the fuzzy matrix $R$ of land resources system in the New Area from 2014 to 2018 is obtained as follows:

$$
\begin{aligned}
& \left.R_{m \times n 2014}=\left(\mathrm{r}_{\mathrm{ij}}\right)=\mid \begin{array}{ccc}
0.65 & 0.35 & 0 \\
0 & 0.6138 & 0.3862 \\
0.1419 & 0.8581 & 0 \\
0 & 0.2219 & 0.7781 \\
0.7360 & 0.2640 & 0
\end{array}\right] \\
& R_{m \times n 2015}=\left(\mathrm{r}_{\mathrm{ij}}\right)=\left|\begin{array}{ccc}
0.4571 & 0.5429 & 0 \\
0 & 0.8646 & 0.1354 \\
0.0972 & 0.9028 & 0 \\
0 & 0.2737 & 0.7263 \\
0.7417 & 0.2583 & 0
\end{array}\right|
\end{aligned}
$$




$$
\begin{aligned}
& R_{m \times n 2016}=\left(\mathrm{r}_{\mathrm{ij}}\right)=\left[\begin{array}{ccc}
0.4143 & 0.5857 & 0 \\
0 & 0.9876 & 0.0124 \\
0.1937 & 0.8063 & 0 \\
0 & 0.2976 & 0.7024 \\
0.7690 & 0.2310 & 0
\end{array}\right] \\
& R_{m \times n 2017}=\left(\mathrm{r}_{\mathrm{ij}}\right)=\left[\begin{array}{ccc}
0.1857 & 0.8143 & 0 \\
0.1032 & 0.8968 & 0 \\
0 & 0.922 & 0.078 \\
0 & 0.58 & 0.42 \\
0.5417 & 0.4583 & 0
\end{array}\right] \\
& R_{m \times n 2018}=\left(\mathrm{r}_{\mathrm{ij}}\right)=\left[\begin{array}{ccc}
0.0429 & 0.9571 & 0 \\
0.8102 & 0.1898 & 0 \\
0 & 0.9083 & 0.0917 \\
0 & 0.6867 & 0.3133 \\
0.0768 & 0.9232 & 0
\end{array}\right\rfloor
\end{aligned}
$$

Secondly, calculate the comprehensive evaluation matrix. Through fuzzy transformation, take 2014 as an example, get the comprehensive evaluation matrix $B$ of land resources system in Xiong'an New Area:

$$
\begin{aligned}
& B_{2014}=W * R \\
& =(0.212,0.224,0.211,0.193,0.160) *\left[\begin{array}{ccc}
0.65 & 0.35 & 0 \\
0 & 0.6138 & 0.3862 \\
0.1419 & 0.8581 & 0 \\
0 & 0.2219 & 0.7781 \\
0.7360 & 0.2640 & 0
\end{array}\right] \\
& =(0.2855,0.4778,0.2367)
\end{aligned}
$$

In this way, the comprehensive evaluation Matrix $B$ of the land resource system in Xiong'an New Area from 2015 to 2018 is calculated in turn: $B{ }_{2015}=(0.2361,0.5934,0.1705), B$ ${ }_{2016}=(0.2517,0.61,0.1383), B{ }_{2017}=(0.1491,0.7378,0.1131), B$ $2018=(0.2029,0.7173,0.0798)$.

In summary, based on Formula 3, the evaluation results of land resources carrying capacity in Xiong'an New Area from 2014 to 2018 are as follows in Table 11, the evaluation results of land resource carrying capacity in Xiong'an New Area have a higher degree of subordination for $v_{1}$ and $v_{2}$, indicating a higher development potential. From the analysis of comprehensive evaluation results, the carrying capacity of land resources in the new district fluctuated between 0.51 and 0.56 from 2014 to 2018 , which increased by $6.4 \%$ compared with 2014.

Table 11 Evaluation results of land resources carrying capacity in Xiong'an New Area from 2014 to 2018

\begin{tabular}{cccccc}
\hline Area name & Year & Evaluation results $v_{1}$ & Evaluation results $v_{2}$ & Evaluation results $v_{3}$ & $\begin{array}{c}\text { Comprehensive } \\
\text { evaluation results }\end{array}$ \\
\hline & 2014 & 0.2855 & 0.4778 & 0.2367 & 0.5220 \\
& 2015 & 0.2361 & 0.5934 & 0.1705 & 0.5295 \\
Xiong'an & 2016 & 0.2517 & 0.61 & 0.1383 & 0.5511 \\
New Area & 2017 & 0.1491 & 0.7378 & 0.1131 & 0.5162 \\
& 2018 & 0.2029 & 0.7173 & 0.0798 & 0.5554
\end{tabular}

C. Evaluation of water resources carrying capacity in Xiong'an New Area

Step 1: Set grading standard of evaluation index.

(1) Per capita water resources. According to international general standards, those with per capita water resources of more than $2000 \mathrm{~m}^{3}$ are water rich areas, those with per capita water resources of $1000-2000 \mathrm{~m}^{3}$ are vulnerable areas, those with per capita water resources of 500-1000 $\mathrm{m}^{3}$ are in short supply areas, and those with per capita water resources of less than $500 \mathrm{~m}^{3}$ are water poor areas. The national per capita water resources level is $1956 \mathrm{~m}^{3}$, Baoding city is $287 \mathrm{~m}^{3}$ and Xiong'an New Area is $144 \mathrm{~m}^{3}$. Referring to international standards and relevant literature, so $k_{1}$ is selected as 2000 and $k_{3}$ as 1000. (2)

Per unit effective irrigation area. The national per unit 
effective irrigation area is $700 \mathrm{~m}^{2} / \mathrm{t}$, Hebei province is $2400 \mathrm{~m}^{2} / \mathrm{t}$ and Xiong'an New Area is $4300 \mathrm{~m}^{2} / \mathrm{t}$. Combined with the relevant research results, so $k_{1}$ is selected as 3000 and $k_{3}$ as 1000. (3) Utilization rate of water resources. According to the international general standards, the utilization rate of water resources is about $15 \%$ in the wet area, about $15 \%$ 25\% in the vulnerable area, about $25 \% \sim 50 \%$ in the short area, and more than $50 \%$ in the poor water area. The national average utilization rate of water resources is about $25 \%$, while the utilization rate of Xiong'an New Area is $127 \%$, so $k_{1}$ is selected as 25 and $k_{3}$ as 50. (4) Water use efficiency. The national average level of water use efficiency is $57 \mathrm{yuan} / \mathrm{m}^{3}$ and Xiong'an New Area is 61.71 yuan $/ \mathrm{m}^{3}$. Combined with relevant references and expert opinions, so $k_{1}$ is selected as 100 and $k_{3}$ as 50. Through the above grading standard selection process, determine the grading standard of water resources carrying capacity evaluation index in the New Area, as shown in Table 12.

Table 12 The grading standard of water resources carrying capacity evaluation index in Xiong'an New Area

\begin{tabular}{|c|c|c|c|c|}
\hline \multirow{2}{*}{ Name } & \multirow{2}{*}{ Evaluation indexes } & \multicolumn{3}{|c|}{ Evaluation classification $v$} \\
\hline & & $v_{1}$ & $v_{2}$ & $v_{3}$ \\
\hline \multirow{4}{*}{ resources } & Per capita water resources $\left(\mathrm{m}^{3}\right.$ per capita) & $>2000$ & $2000 \sim 1000$ & $<1000$ \\
\hline & Per unit effective irrigation area $\left(\mathrm{m}^{2} / \mathrm{t}\right)$ & $>3000$ & $3000 \sim 1000$ & $<1000$ \\
\hline & Utilization rate of water resources $(\%)$ & $<25$ & $25 \sim 50$ & $>50$ \\
\hline & Water use efficiency $(\%)$ & $>100$ & $100 \sim 50$ & $<50$ \\
\hline
\end{tabular}

Step 2: Determine the weight of each index.

Step 3: Evaluate the carrying capacity of water resources.

Through Step2 and Step3, in this way, the comprehensive evaluation Matrix B of the water resource system in Xiong'an New Area from 2014 to 2018 is calculated in turn: $B$ ${ }_{2014}=(0.2094,0.4338,0.3568), B_{2015}=(0.2221,0.4389,0.3390)$, $B_{2016}=(0.2285,0.4024,0.3691), B_{2017}=(0.2285,0.4024$, $0.3691), B_{2018}=(0.2810,0.3837,0.3353)$.

In summary, based on Formula 3, the evaluation results of water resources carrying capacity in Xiong'an New Area from
2014 to 2018 are as follows in Table 13, the evaluation results of water resources carrying capacity of Xiong'an New Area from 2014 to 2018 have a large degree of membership to $v_{2}$, indicating that there is a certain development potential, and the membership to $v_{1}$ shows an upward trend. From the analysis of the comprehensive evaluation results, as the economic development speed of the New Area increased in 2016, the amount of water resources used exceeded the load, which reduced the water resources carrying capacity to a certain extent. As a whole, as the New Area strengthened the management and utilization of water resources in 2017, the water resources carrying capacity is in a gradual upward trend.

Table 13 Evaluation results of water resources carrying capacity in Xiong'an New Area from 2014 to 2018

\begin{tabular}{cccccc}
\hline Area name & Year & Evaluation results $v_{1}$ & Evaluation results $v_{2}$ & Evaluation results $v_{3}$ & $\begin{array}{c}\text { Comprehensive } \\
\text { evaluation results }\end{array}$ \\
\hline & 2014 & 0.2094 & 0.4338 & 0.3568 & 0.4337 \\
& 2015 & 0.2221 & 0.4389 & 0.3390 & 0.4474 \\
Xiong'an & 2016 & 0.2285 & 0.4024 & 0.3691 & 0.4367 \\
New Area & 2017 & 0.2741 & 0.3980 & 0.3279 & 0.4758 \\
& 2018 & 0.2810 & 0.3837 & 0.3353 & 0.4756 \\
\hline
\end{tabular}

D. Evaluation of mineral resources carrying capacity in Xiong'an New Area

Step1: Set grading standard of evaluation index

(1) Ore production per unit land use. The national ore production per unit land use is 5.6 million $\mathrm{t} / \mathrm{km}^{2}$, Hebei province is 6.25 million $\mathrm{t} / \mathrm{km}^{2}$ and Xiong'an New Area is $792.70 \mathrm{t} / \mathrm{km}^{2}$. Referring to relevant literature, $k_{1}$ is selected as 750 and $k_{3}$ as 600. (2) Annual crude oil production. The annual crude oil production in China is 175.9 million t/year, and that in Hebei province is 5.2 million $\mathrm{t} / \mathrm{year}$, ranking the eighth. The annual 
crude oil production of Xiong'an New Area is 93.2t/year, which is higher than the average level of Hebei Province. Combined with relevant research results, $k_{1}$ is selected as 80 and $k_{3}$ as 50 .

(3) Annual natural gas production. The national annual natural gas production is more than 160 billion $\mathrm{m}^{3}$, and Hebei province is 620 million $\mathrm{m}^{3}$, ranking the 13th. The annual natural gas production of Xiong'an New Area is 2010 million $\mathrm{m}^{3}$. Therefore, $k_{1}$ is selected as 2000 and $k_{3}$ as 1000. (4)
Geothermal field area. The geothermal field in Xiong'an New Area is $670 \mathrm{~km}^{2}$, far exceeding the national average standard of $280 \mathrm{~km}^{2}$. In combination with relevant references and expert opinions, $k_{1}$ is selected as 500 , and $k_{3}$ as 300 . Through the above grading standard selection process, determine the grading standard of mineral resources carrying capacity evaluation index in the New Area, as shown in Table 14.

Table 14 The grading standard of mineral resources carrying capacity evaluation index in Xiong'an New Area

\begin{tabular}{|c|c|c|c|c|}
\hline \multirow{2}{*}{ Name } & \multirow{2}{*}{ Evaluation indexes } & \multicolumn{3}{|c|}{ Evaluation classification $v$} \\
\hline & & $v_{1}$ & $v_{2}$ & $v_{3}$ \\
\hline & ore production per unit land use $\left(10000 \mathrm{t}\right.$ per $\left.\mathrm{km}^{2}\right)$ & $>750$ & $750 \sim 600$ & $<600$ \\
\hline Mineral & annual crude oil production(t per year) & $>80$ & $80 \sim 50$ & $<50$ \\
\hline resources & annual natural gas production $\left(10000 \mathrm{~m}^{3}\right)$ & $>2000$ & $2000 \sim 1000$ & $<1000$ \\
\hline & geothermal field area $\left(\mathrm{km}^{2}\right)$ & $>500$ & $500 \sim 300$ & $<300$ \\
\hline
\end{tabular}

Step 2: Determine the weight of each index.

Step 3: Evaluate the carrying capacity of mineral resources

Through Step 2 and Step 3, in this way, the comprehensive evaluation Matrix B of the mineral resource system in Xiong'an New Area from 2015 to 2018 is calculated in turn: $B$ ${ }_{2014}=(0.6090,0.3910,0), B{ }_{2015}=(0.6229,0.3771,0), B$ ${ }_{2016}=(0.6625, \quad 0.3375,0), B{ }_{2017}=(0.6279, \quad 0.3721,0), B$ $2018=(0.6540,0.3460,0)$.
In summary, based on Formula 3, the evaluation results of mineral resources carrying capacity in Xiong'an New Area from 2014 to 2018 are as follows in Table 15, the evaluation results of mineral resources carrying capacity of the New Area from 2014 to 2018 have a large degree of subordination to $v_{1}$, indicating a large development potential. From the analysis of the comprehensive evaluation results, the mineral resources carrying capacity in the New Area shows an upward trend from 2014 to 2018.

Table 15 Evaluation results of minreal resources carrying capacity in Xiong'an New Area from 2014 to 2018

\begin{tabular}{|c|c|c|c|c|c|}
\hline Area name & Year & Evaluation results $v_{1}$ & Evaluation results $v_{2}$ & Evaluation results $v_{3}$ & $\begin{array}{c}\text { Comprehensive } \\
\text { evaluation results }\end{array}$ \\
\hline \multirow{5}{*}{$\begin{array}{l}\text { Xiong'an } \\
\text { New Area }\end{array}$} & 2014 & 0.6090 & 0.3910 & 0 & 0.7741 \\
\hline & 2015 & 0.6229 & 0.3771 & 0 & 0.7671 \\
\hline & 2016 & 0.6625 & 0.3375 & 0 & 0.7981 \\
\hline & 2017 & 0.6279 & 0.3721 & 0 & 0.7826 \\
\hline & 2018 & 0.6540 & 0.3460 & 0 & 0.7943 \\
\hline
\end{tabular}

E. Evaluation of resources carrying capacity in Xiong'an New Area

Using the expert scoring method, the corresponding weights of land resources, water resources and mineral resources of Xiong'an New Area are 0.4, 0.4 and 0.2 respectively. The Formula 4 as followed is used, $w_{i}$ given to the evaluation value of land resources, water resources and mineral resources in the comprehensive evaluation, $B_{i}$ represents the evaluation value of the carrying capacity of land resources, water resources and mineral resources.

$$
Z=\sum w_{i} * B_{i}
$$

The evaluation results of resource carrying capacity in Xiong'an New Area from 2014 to 2018 are obtained, as shown in Fig 2. The resource carrying capacity of Xiong'an New Area shows an upward trend from 2014 to 2018, and the value 
fluctuates from 0.53 to 0.58 , so the resource carrying capacity is good. Since 2017, the construction of the New Area has been strengthened, and the resource carrying capacity is on the rise.

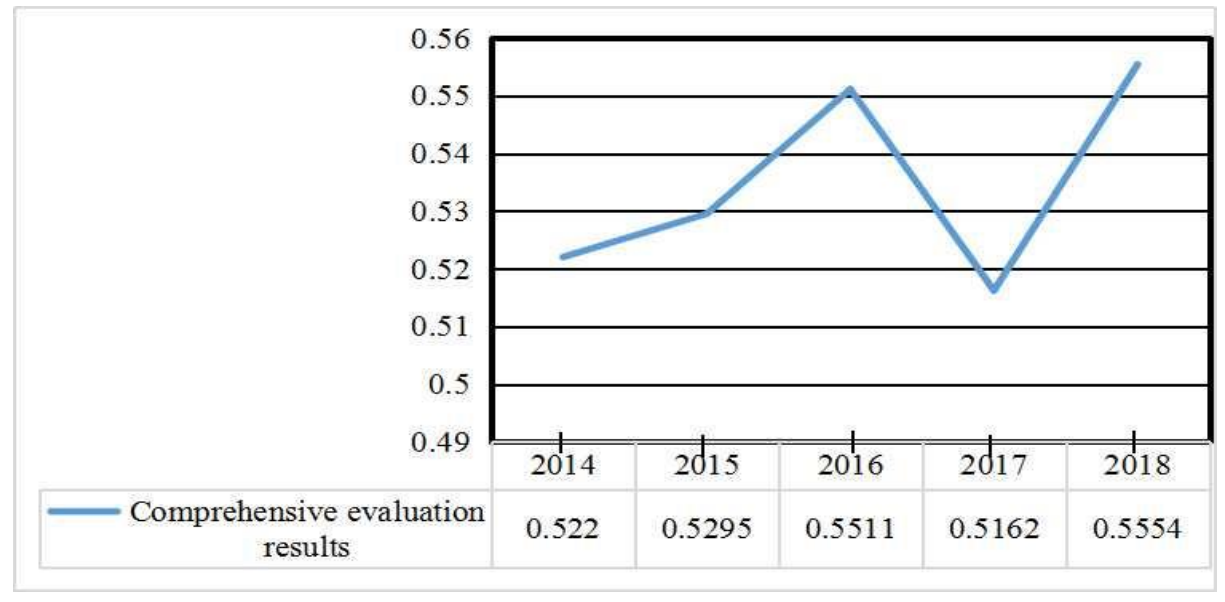

Fig. 2 The evaluation results of resource carrying capacity in Xiong'an New Area from 2014 to 2018

\section{CONCLUSION}

Based on the analysis of the current situation of land resources, water resources and mineral resources in Xiong'an New Area, using the evaluation index system of resource carrying capacity in the New Area, the statistical data of 2014-2018 is seleted to analyze the carrying capacity of land resources, water resources and mineral resources. On this basis, it makes a comprehensive analysis of the carrying capacity of resources in the New Area. The conclusion is as follows:

1) From 2014 to 2018, the carrying capacity of land resources in Xiong'an New Area is 0.5220, 0.5295, 0.5511, 0.5162 and 0.5554 respectively. Compared with 2014, the land resources carrying capacity has increased $62.07 \%$ in 2018.

2) From 2014 to 2018, the water resources carrying capacity of Xiong'an New Area is 0.4337, 0.4474, 0.4367, 0.4758 and 0.4756 respectively. Due to the acceleration of economic development in 2016, the use amount of water resources is increased significantly, and the water resources carrying capacity decreased to a certain extent. On the whole, the water resources carrying capacity of the New Area is in a slow rising trend, maintaining an annual growth rate of about $2.5 \%$.

3) From 2014 to 2018, the carrying capacity of mineral resources in Xiong'an New Area is 0.7741, 0.7671, 0.7981, 0.7826 and 0.7943 respectively, which is with great potential. Compared with 2014, the mineral resources carrying capacity increased by $2.61 \%$ in 2018 .

4) From 2014 to 2018 , the resource carrying capacity of the Area is $0.5371,0.5442,0.5547,0.5533$ and 0.5713 respectively, which belong to the medium level. As the New Area strengthened resource management from 2017, the resource carrying capacity showed an obvious upward trend, with an annual growth rate of $3.25 \%$.

\section{ACKNOWLEDGMENT}

This study were supported by the Beijing Social Science Foundation Project (No. 18LJB004).

\section{References}

[1] Research group of Research on Evaluation and regulation of resource and environment carrying capacity in Xiong'an New Area, "Research on Evaluation and regulation of resource and environment carrying capacity in Xiong'an New Area," Journal of Chinese Academy of Sciences, vol. 32, no. 11, pp. 1206-1215, Nov. 2017.

[2] Zhai Weixin, Cheng Chengqi, Chen Bo, (2019): "Land use change detection in Xiong'an New Area from 2014 to 2018 based on Landsat Image," Geographic information world, vol. 26, no. 4, pp. 38-43, Apr. 2019.

[3] Yang Jiangyan, "Land use change and ecological quality assessment of Xiong'an New Area Based on Remote Sensing," Hebei Agricultural University, Jun. 2019.

[4] Kang Zhenhai, "Hebei Economic Development Report (2018 2019)," Social Sciences Literature Press, March. 2019.

[5] Boyang Sun, Xiaohua Yang Yanzhan, "Simulation of Water Resources Carrying Capacity in Xiong'an New Area Based on System Dynamics Model," Water, vol. 11, no. 5, pp. 1085-1096, May. 2019.

[6] Zhao Zhibo, Zhao Lingdi, Wang Yawei, Yuan Tian, "Analysis of water resource utilization efficiency and water saving potential in Xiong'an New Area under different scenarios," Journal of natural resources, vol. 34, no. 12, pp. 2629-2642, Dec. 2019.

[7] Zhang Wanyi, Jia Delong, Wang Yao, Yao Xiaofeng, "Geological survey: the construction of Xiong'an New 
Area first 'find out'." China development observation, Vol. 8, pp. 22-23, Aug. 2017.

[8] Ma Hailong, "Study on carrying capacity of resources and environment in Ningxia," Beijing: Science Press, 2017, pp. 49.

[9] Wang Hongqi, "Study on evaluation indexes of resource and environment carrying capacity of important ecological functional areas in China," Beijing: Science Press, 2017, pp. 46-47.

[10] Fan Zhou, "Research Report on the development of xiong'an New Area (Volume IV)," Beijing: Intellectual Property Press, 2017, pp. 20-35.

[11] Wang Shuqiang, $\mathrm{Xu} \mathrm{Na}$, Comprehensive evaluation of ecological environment carrying capacity of Xiong'an New Area. Economic and management research, vol. 38, no. 11, pp. 31-38, Nov. 2017

[12] Liu Lei, "Evaluation of regional resources and environment carrying capacity and strategic choice of land planning and development -Taking Wanjiang urban belt as an example," Beijing: People's Press, 2013, pp. 84-89.

\section{Creative Commons Attribution License 4.0 (Attribution 4.0 International, CC BY 4.0)}

This article is published under the terms of the Creative Commons Attribution License 4.0

https://creativecommons.org/licenses/by/4.0/deed.en_US 